\title{
A CIVIL KEZDEMÉNYEZÉSEK HATÁSA A VÁROSI KORMÁNYZÁSRA
}

\author{
(Impact of Civil Initiation on Local Governance)
}

\author{
BRACHINGER TAMÁS
}

Kulcsszavak:

részvételi demokrácia társadalmi részvétel civil társadalom civil szervezet governance Az integráció, a kooperáció, az együttmüködés fogalmaival leirható jövó és az ezekhez nélkülözhetetlen részvétel szükséges feltétele a helyi társadalom kibontakozásának. $A$ helyi közösség, a lakópolgárok társulásai nem "belsö ellenörei", hanem egyenrangú partnerei a helyi hatalomnak. Sokkal hitelesebb, ha az együtt-tanulás eredményeképpen civilek maradnak, tehát ïgyelnek arra, hogy autentikusak legyenek.

\section{Bevezetó}

A politikatudomány számára - elsősorban a helyi politikai cselekvés szintjén -, figyelemre méltó jelenségek elöidézőivé váltak a civil szerveződések. Az önkormányzatiság fogalma nemzetközi használatban inkább utal a helyi közösségek önigazgatására, semmint a helyi hatalomgyakorlás legitim, de közvetett formájára.

A governance új jelentésváltozata, annak lokális adaptációja, új távlatokat nyit a helyi közösségek tudatosabb és tervszerübb részvétele, a szektorközi együttmüködés vonatkozásában. A civil kezdeményezések - a helyi társadalmak változatosságára is figyelemmel - hol a politikai versenyben, hol a közpolitikák alakításában, hol az állampolgári részvétel demokrảciát kiteljesítỏ alternatív formáinak kiépítésében vállalnak szerepet. Az ezektöl várt eredmények illetve következmények rendkívül eltéröek az egyes településeken. A civil szerveződések illetve az önkormányzatok, az egymással való együttmüködés többféle módját dogozták ki. Az átfogó, koncepciózus kooperáció kezdeményezöi egyelőre inkább az önkormányzatok. Talán ezzel is demonstrálni kívánják elkötelezettségüket a népakarat érvényesítésében, de szándékuk lehet pusztán szépségtapasz! Másfelöl, a civil szervezetek és képviselöik sem feltétlenül a fejlett demokráciákban kialakított technikákat szorgalmazzák „társadalmi ellenörző" tevékenységük során, hanem a politikai pártok magatartásához igazítják saját viselkedésüket személyi vagy szervezeti szinten. Nyitott még az a kérdés, vajon mekkora civil kurázsi halmozódik fel a döntések elökészítése, -ellenörzése és a közfeladatok ellátása tekintetében?

Az időrendiség szempontjából érdemes megjegyezni, hogy a negyedik önkormányzati választási ciklusban (2002-) - különösen a megyei jogú városokban megindult a koncepcióalkotási trend. A szóban forgó jelenség elterjedésében szerepet játszhatott a kormány 2003-ban elfogadott civil stratégiája. 


\section{Településközösség versus helyi hatalom?}

A magyar önkormányzati rendszer másfél évtizedes fejlődésének megítéléséhez véleményünk szerint - hozzátartozik a helyi közösségek (mint önálló komponens) viszonya a településközösség müködéséhez és múködtetéséhez, valamint az ennek érdekében kifejtett helyi hatalomgyakorláshoz. A felsorolt dinamikus fogalmak a köztudatban úgy élnek, hogy azok ad absurdum önkormányzati kompetenciák. Az önkormányzat illetékességéé, mint önálló entitásé, amely nem feltétlenül ér össze a helyi közösségekkel. A helyi hatalom (helyi önkormányzat) vajon milyen mélyen ágyazott a helyi társadalmat alkotó helyi közösségekbe? Egyáltalán, ezek a helyi közösségek mennyire állékonyak, elérték-e a szervezettség optimális fokát, amelyben világos mission statement-tel, valamint személyfüggetlen kontinuitással rendelkeznek?

A hatalom származtatásának dilemmája különösen élesen vetődik fel térségünkben, ahol az önkormányzati alapjogok biztosítása egyfajta történelmi kárpótlásként is jelentkezett a tanácsrendszerböl kilépö települések (helyhatóságok) számára. A jogalkotó munka során ügyelni kellett a helyi közösség autentikusságára (legalább pro forma), de a polgári demokratikus hagyományoknak megfelelöen a központi hatalom - a szocialista politikai rendszertől eltérő - primátusa mellett. Az önkormányzati alapjogokat, az előbbi logikának megfelelően, az alábbi alapjogszabályok biztosítják: az 1949. évi XX. törvény a Magyar Köztársaság Alkotmányáról, valamint az 1990. évi LXV. törvény a helyi önkormányzatokról. Így a helyitelepülési önkormányzat nem a helyi közősség önigazgatására, hanem egy - kétség kívül demokratikus -, de mégiscsak államon (állami szférán) belüli - alkotmányos alapokon álló - közhatalmi konstrukcióra utaló fogalom.

A helyi közösség önigazgatása alulról épülhet fel, és az eddigi tapasztalatok azt mutatják, hogy jóval lassabb a kibontakozás - természetesen települések közötti eltérések azért vannak -, mint amire az önkormányzati rendszer kialakítása során számítani lehetett. A helyi közösségekbe való bevonás sikere, a kereteket megtestesító manifesztációk állapotán (itt ad hoc vagy tartós civil szervezetek) is múlik. A szervezetek minőségét pedig a következö tényezők determinálják: szervezettség, világos ön- és jövőkép, küldetéstudat, hatékony kommunikáció, hosszú távú, konvergens szervezeti célok, stabil és aktív tagság stb. Miután egy-egy community study keretében tisztázzuk, hogy az itt említett feltételek - az adott településközősség szintjén - adottak-e, érdemes beszélni a helyi hatalom és a helyi közösségek viszonyáról. Az érdekeltek viszonya egyébként - az eddigi tapasztalatok szerint lehet konfrontatív, kompetitív és kooperatív. A felsorolt három magatartási megnyilvánulásból az első kettő inkább „gyermekbetegség”. A kompetitív magatartás egyenesen szerepértelmezési probléma, amelynek lényege, hogy egyik-másik helyi civil szervezet a politikai verseny részesévé kíván válni, csakhogy az önkormányzati rendszer közhatalmi és a helyi közösség önrendelkezési dimenziója - erre utaltunk korábban - nem ezen a síkon esik egybe. 
A közjogi és a politikai dimenzió közelítése mindenesetre kívánatos, hiszen „,a lokális közösség embereknek olyan területi, szomszédsági alapokon szerveződö közössége, amely össztársadalmi meghatározottsága mellett ... rendelkezik a politikai részvétel, érdekérvényesités esélyével, melynek közvetlen bázisát a lakóhellyel szemben támasztott igények, követelmények azonossága biztosítja." (Pálné 1990, 40) Bőhm Antal az önkormányzatiságról szólva Bibót interpretálva írja: ,az önkormányzatok a kisebb közösségek szabad közéletének az iskolái, az egyes emberek számára hozzáférhetô és nélkülözhetetlen kellékei a társadalmi demokráciának." (Böhm 1996, 64)

\section{Elöfeltevések}

A tanulmány egyfajta kronológiai utat kíván bejárni, amely az önkormányzati rendszer 17 éves idószakának fontosabb állomásait próbálja rendszerezni a civil szervezetek és a helyi hatalom kapcsolatában. Úgy értékeljük, hogy az elmúlt másfél évtized elöhívta azokat a problémákat - esetenként azok orvoslását is (ez akár modellértéküvé is válhat) -, amely már indokolja a másfél évtized áttekintését, a tanulságok levonását. Az alábbiakban, ha nem is mindig a kívánatos, de a lehetséges perspektívákra utalunk:

1) Idővel tudatosabbá és professzionálisabbá válnak a megfeleló ön- és jövöképpel, misszióval és szervezettséggel rendelkezö civil szerveződések.

A civil szervezetek extenzív fejlödése a kilencvenes években ment végbe. Az adatok ugyan a statisztikai valóságot tükrözik (sic!), de a szervezetek tényleges múködésére, az aktivisták, az önkéntesek, a tagság részvételének elmélyültségére nem kapunk választ. A jogi és a politikai környezet kedvezó változása, évtizeddel később a gazdálkodási lehetőségek könnyítése, szükséges feltételei voltak a civil társadalom konszolidációjának, de továbbra sem állt elő a kívánatos állapot. A tartós és a célratartó müködés komoly hiányosságokat mutat a kisebb, de gyakori szervezetméretnél, amely a lokális és valóban polgári kezdeményezésre létrehozott szervezetek többségére jellemző. Ezen sokat segíthet a civil infrastruktúra (3), valamint hosszabb távon a felsőoktatás, illetve a piaci szervezeteknél kialakított gyakorlat tanulmányozása és körültekintő (módosított) alkalmazása. A társadalmi feltétel kibontakozása is akadályokba ütközik, amelyet a bevezetőben említett állampolgári, társadalmi részvétel elégtelensége okoz.

2) A nonprofit szervezetek egymással történö együttműködése feltétele a települési szintú együttmúködésnek az adott település önkormányzatával (a helyi hatalommal), ezért mást jelent sikeresen együttmúködni egy partikuláris érdekeit érvényesítő, -képviselő szervezetnek a helyi hatalommal, mint közösen fellépni a sajátos „civil érdekek" képviseletében, kompakt közösségként.

Az igazi kihívást - az önkormányzatiság eddig eltelt időszakának tapasztalatai alapján - ennek a magatartásnak a napi gyakorlattá válása jelenti, hiszen a szervezeteknek arra a képességére utal, tudnak-e az egyébként partikuláris érdekeik képvise- 
lete közben - mondjuk egy településközösség szintjén - más civil szervezetekkel közösen fellépni, tartósan együttmüködni az önkormányzattal szemben?

3) Az önkormányzatok átgondolják a civil szervezetekkel kapcsolatos magatartásukat. Ennek lehetséges okai között említhetjük az elegendő tanulóidőt, tehát azt az idökeretet, amelyben az érdekeltek, megismerték egymás szándékait, céljait, jellegzetes vonásait.

A normativitás, a kiszámíthatóság kölcsönös igénnyé válik.

\section{A kormányzat és az önkéntes szervezetek együttmüködésének általános indokai}

A kilencvenes évtizedben jelentős fordulat állt be a civil kezdeményezésekkel kapcsolatos európai közfelfogásban, sőt, a nyugat-európai kormányzatok, az Európai Unió magatartásában is. Az Európai Unió Bizottsága, „A Bizottság közleménye az önkéntes szervezetek és alapitványok szerepének erösitéséröl Európában" címmel 1997-ben dokumentumot adott ki.

Lester M. Salamon „Az öntevékenység kudarcának elmélete” című tanulmányában, a kormány és a nonprofitok közötti együttmúködés lehetöségeivel kapcsolatban megjegyzi; ,a kormány egyre nagyobb mértékben bizza nonprofit szervezetekre az állami finanszírozású termékek, szolgáltatások elöállítását. Néha még az is előfordul, hogy ilyen célokra maga a kormány hoz létre nonprofit szervezeteket QUANGO-k -, ha azok maguktól nem jönnek létre." (Brachinger 2000, 45) $\mathrm{Az}$ elmélet feltétlenül adaptálható tanulsága, hogy különbséget tesz a kormány intézményfenntartó (mindenható) és a kormány feladatfinanszírozó magatartása között. A redisztribúció gyakorlatának horizontális kiterjesztésére utal, hiszen a feladatfinanszírozás egyúttal a szektorok közötti átjárás lehetőségét adja meg a közfeladatok elöállításában. Az európai jóléti állam modellje inkább kiegészitö, semmint helyettesitő szerepet adott a nonprofit szervezeteknek.

Salamonnak az öntevékenység kudarcáról szóló tanulmánya arra hívja fel a figyelmet, hogy nemcsak a nonprofit szektor igazítja ki az állam által okozott (másodlagos) egyenlötlenségeket, hanem a piac által okozott (elsődleges) egyenlőtlenségek nivellálásán igyekvő öntevékeny szektorral kapcsolatban fellépő hatékonysági, minőségbeli problémák ugyancsak elöidézhetik az állami korrekciós mechanizmusokat. Az európai gondolkodásnak szokatlan sorrend (elöbb a nonprofit szektor, majd ezt követỏen az állami beavatkozás) problémánk - a szektorközi együttmüködés terjedelme és minősége - szempontjából, egyelöre irreleváns. A hangsúly ugyanis a két szektor együttmüködésén van, amely nem egy önmagáért való viszony, mivel abból a nyilvánvaló felismerésből indul ki, hogy mindként szektor szervezetei rendelkeznek mással nem pótolható adottságokkal és meg nem szüntethetỏ korlátokkal. 
Az alábbiakban a két szektorral kapcsolatban megállapított előnyök és hátrányok rövid áttekintését adjuk:

1) A kormányzati szféra müködésének előnyei: általános szolgáltatásokat nyújt, azaz az állami ellátórendszer kiterjedt és univerzalisztikus, a fogyasztók számára viszonylag könnyen elérhető. A feladatok finanszírozásának biztosak a forrásai.

2) A kormányzati szféra müködésének hátrányai: nehézkes, bürokratizált, lobbi érdekek stb.

3) A nonprofit szféra múködésének előnyei: probléma-érzékeny, rugalmas, részt vesz a kormányprogramok megvalósításában, versenyeztetésre ad lehetóséget.

4) A nonprofit szféra mủködésének hátrányai: forrásszerzése esetleges, partikularizmus, paternalizmus, amatőrizmus (Salamon 1991, 65-68).

Ezek az állítások a demokratikus kormányzás másfél évtizedes tapasztalatainak figyelembevételével a hazai viszonyokra is alkalmazhatóvá váltak.

\section{A hazai nonprofit szektor téma szempontjából adekvát sajátosságai és dilemmái}

1) A helyi hatalom pro forma a helyi társadalomé az önkormányzati rendszerben. Az alkotmányban és az önkormányzati törvényben, valamint a legtöbb helyi statútumban manifesztálódott ez a viszony.

2) A helyi hatalom de facto is a helyi társadalomé az önkormányzati rendszerben? A kérdésfelvetésben rejlö bizonytalanság nyilvánvaló oka a településközösség és a helyi hatalom viszonyáról előzőekben tett megjegyzésünk, vagyis a társadalmi részvétel, a közbizalom szórványos érvényesülése a demokráciát inkább „csak” kiegészíti, és nem kiteljesíti.

A nem valódi civil kezdeményezések szerepe meghatározó (volt) a szektorközi munkamegosztásban (közfeladat-ellátások területén). Az 1994-2004 közötti szakaszt a kht-k ,virágzása” időszakának tekinthetjük. Az egyes minisztériumi, valamint az önkormányzati alapitású társaságok jellemzik ezt az etapot, tehát nem a magánszféra kezdeményezésére létrehozott szervezetek váltak tipikussá. A legtöbb alapítás eredeti szándéka nem a feladatellátás stratégiai elemzésén alapult, nem a két szektor előnyeinek egyesítésére irányult. A „kényszer-társadalmasítás” (Kéri 1997, 12) másik formája a közalapítvány lett. Alapításuk célja - az első pontban ismertetett okok mellett - magánforrás bevonása a közcélok, alapvetően az önként vállalt feladatok megvalósítására.

Az említett dilemmát illusztrálja az a séma, amelyet Harsányi László állított fel a hazai nonprofit szektor struktúrájával kapcsolatban. A hazai nonprofit szektor a kilencvenes években, egy triális rendszerben öltött testet, amely a következő összetevőkből áll. 
1) Államközeli szervezetek: ide soroljuk a közalapítványokat és a köztestületeket.

2) Kvázi piaci szervezetek, amelyek alapítója jellemzően az (ön)kormányzat, jogi formájukat tekintve közhasznú társaságok. Kommunális, szociális, közmủvelődési feladatok ellátása, illetve ilyen intézmények müködtetése céljából hozták létre öket.

3) A valódi civil szerveződések, amelyek polgári kezdeményezésre létrehozott keretek. Statisztikai szempontból nagyszámú civil kezdeményezést találunk Magyarországon, de jelentős részük ,alvó” vagy alkalomszerüen müködő szervezet (Brachinger 2000, 106).

\section{Az együttmüködés eddigi szakaszai}

Az alábbiakban megpróbáljuk szakaszolni a lokális civil kezdeményezések és az önkormányzatok kapcsolatának elmúlt tizenöt évét. A másfél évtized adekvát áttekintéséhez három részre osztottuk a szóban forgó időszakot azzal a szándékkal, hogy az egyes etapok jellegzetességeit összefoglalhassuk. A tipizálás segíthet az eligazodásban, de a „közös vonások” az egyes helyi társadalmak szintjén átcsúszhatnak másik szakaszba.

A településeken kibontakozó civil aktivitás szintje és a helyi hatalom helyi közösségekkel kapcsolatos attitüdjei jelenleg is eltéréseket mutatnak. A kapcsolatok dimenziói, valamint a „haszonáramlás” (Sebestény 2002) üteme és irányai különböző tempóban fejlödtek, ami más tényezők mellett, az önkormányzati rendszer bevezetésének köszönhetö, de természetesen, a mélyben meghúzódó, hosszú idő alatt strukturálódott, helyi társadalmi viszonyok is determinálhatták a kontaktusok terjedelmét és intenzitását.

\section{Az együttmüködés I. szakasza: ,romantikus ösállapot”}

- A tanácsrendszer rutinszerü támogatáspolitikájának továbbélése a korábban is mủködő, települési szinten szerveződő, sport- és szabadidös egyesületek vonatkozásában. Ezek a szervezetek továbbra is „kiszámítható” partnernek minősülnek, föleg a kontinuitást képviselő és a helyi viszonyok alapos ismeretével rendelkező hivatali apparátusnak köszönhetően.

- Alkalmi, spontán együttmúködések, amelyek nélkülözik a koncepciózus, tervszerủ kooperációt. Az új helyi hatalmi elit gyakran állt közeli kapcsolatban azokkal a civil kezdeményezésekkel, amelyek a rendszerváltás társadalmi folyamatában születtek. Az új hatalom gyakran őket minősítette hitelesnek, ezért a kapcsolatépités, a támogatási szándék az ö irányukban vált intenzívvé. A felek, az intézményes tapasztalatok hiányában, inkább a perszonális kapcsolatokat preferálták, ami meglehetősen kiszámíthatatlanná, rapszodikussá tette a viszonyukat és ezzel bizonytalanná vált a partnerség jövője. 
- A kompetitív magatartás kialakulása, amelynek részeként egyes civil szervezetek politikai szerepvállalásba fogtak és ez sok-sok szerepkonfliktussal, meghasonlással járt együtt. Eredménye: bekapcsolódás a helyi hatalomgyakorlásba.

Az együttmüködés II. szakasza: „köztes helyzet”(Csegény-Kákai 2000)

- Az együittmüködés formalizálódásának időszaka, amely elsősorban a helyi statútumokban (SZMSZ), továbbá munkakörökben (civil referens), egyeztetésekben (civil fórumok, kerek asztalok) manifesztálódik.

- A támogatáspolitika átalakul, ami a pályázati rendszerek kidolgozásában és a költségvetési keretek normatívabb felhasználásában ölt testet.

- Az önkormányzati szervezet-alapítás extenzív szakaszának tekinthetjük ezt az időszakot, köszönhetően a Polgári Törvénykönyv 1993. évi módosításának, amely többek között a közalapítvány és a közhasznú társaság jogformáját vezette be 1994. január 1-jei hatállyal. A törvényi változás hatására számtalan önkormányzat vált nonprofit szervezet alapítójává. A közalapítványokat elsősorban finanszírozási, a közhasznú társaságokat feladat-ellátási, intézmény fenntartási céllal alapították.

- A jogi feltételekben progressziv változás az 1997. évi CLVI. törvény a közhasznú szervezetekröl címú jogszabály megalkotása. A közhasznúság jogilag is explicitté tette a társadalmilag hasznos tevékenységeket, továbbá bevezette a kiemelkedően közhasznúsági szintet, az állami-, önkormányzati feladatok átvállalására ösztönző minösítést. A közhasznú minősités bevezetésének tanulságos következménye, hogy a kiemelkedően közhasznú minősítést (amely addig példátlan kedvezményeket adott a szervezeteknek, azok támogatóinak, illetve kedvezményezettjeinek) kérő nonprofit szervezetek meghatározó részét az önkormányzatok alapították, közpénzből és „politikai akaratból”.

A törvény hatálybalépését követően a valódi civil öntevékenység, a társadalmi aktivitás egyáltalán nem növekedett, sőt, a kisebb szervezetek számára az új körülményekhez való alkalmazkodás komoly kihívást is jelentett.

- Az Orbán-kormány idején, a kancellárián belül hozták létre a civil társadalommal foglalkozó kormányzati „csúcsszervet”, a „Civil Kapcsolatok Főosztályát”. A szervezet a kormányváltást követően „Kormányzati Civil Kapcsolatok Főosztálya néven, az Esélyegyenlöségi-, később az Ifjúsági, Szociális, Családügyi és Esélyegyenlöségi-, majd a II. Gyurcsány-kormány megalakulását követően a Szociális és Munkaügyi Minisztérium szervezeti egységévé vált.

- Az Orbán-kormány idején épült ki a „vidéki” civil infrastruktúra, amely a hazai sajátosságokat tükrözve, a kormányzat kezdeményezésére indult el. A kormány, a hálózat kiépítését pénzügyileg is támogatta. Az intézkedés eredményeként a megyeszékhelyeken megalakultak a Nonprofit Szolgáltató Központok. $\mathrm{Az}$ elöbbiekben felsorolt tényezők következtében állandósult az a kettőség, amely a hazai civil szervezetek adekvát részének identitását, de gyakorlati 
müködését is determinálta és ennek megfelelően hatott az önkormányzatok civilekkel alakuló viszonyára is. Egyrészt manifesztálódott, majd ciklusrólciklusra erősödött a döntésekben való közvetlen civil részvétel szándéka (képviselöi mandátum, külső bizottsági tagság). A negyedik önkormányzati választáson már a pártokkal kötött, ún. vegyes szövetségek a relevánsak, amely figyelmeztet az útkeresés ilyen változatának a veszélyeire.

Előnye: erős érdek-aggregáció (igaz, nem a teljes lokális civil oldalnak, hanem partikulárisan)

Hátránya: a civil szereplő elveszti autentikusságát, fủggetlenségét.

Másrészt a döntés-elökészítésbe (kezdeményezés, javaslattétel, véleményezés), amelyet a „felvilágosult” önkormányzatok a helyi statútumokban rendeztek (Csegény-Kákai 2000), és/vagy a nonprofit szervezetek társadalmilag fontos célokkal kapcsolatos feladatok ellátásába történő bevonása.

Előnyei: nagyfokú szervezettséget, konszenzusos demokratikus attitűdöket, a feladatellátáshoz szakszerüséget igényel; közvetlenebb lakossági részvételellenörzés; autentikusabb feladatellátás, versenyhelyzet.

Hátrányai: az egyes szervezetek, illetve szövetségeik a települési döntéseket csak közvetve képesek befolyásolni; a helyi statútumokban szabályozott jogosítványok gyakran formálisnak tekinthetök; nagyfokú látencia gerjesztői a személyi átfedések; a közfeladatok ellátásának ellenörzése nehézkes; a meglévő példák jelentős része megtéveszthet (kht-k, közalapítványok, költségvetési intézmények szatellit alapítványai).

\section{Az együttmüködés III. szakasza: „normativitásra törekvés”}

- A kormány 2003-ban fogadta el civil stratégiáját. Alapelveiben ,,Autonóm civil társadalmat partnerének tekintö állam"-ról beszél. Hangsúlyozza a civil szervezetek függetlenségét, más szóval a politikai függőség megszüntetését deklarálja. A dokumentum kiemeli az önkéntesség és az öntevékenység társadalmi hasznát. A stratégia hangsúlyozza a társadalmi párbeszéd, a nyitott jogalkotás gyakorlatának fontosságát, a finanszírozásban, a feladatellátásban pedig a szektorsemlegesség elvét. A stratégia a kormány, az önkormányzatok céljai között említi a feladat-kihelyezést, a közfeladat-ellátásban történő együttmúködést. A stratégiai célok között található a szektor legitim képviseletének a szándéka, ami a civil társadalom belügye (sic!)

- A kormány civil stratégiájának egyik kézzelfogható eredménye a Nemzeti Civil Alapprogramról (NCA) szóló törvény megalkotása (2003. évi L. törvény). Az NCA-ról szóló törvény az első jogszabály, amely definiálja a civil szervezetet, ezzel nemcsak szociológiai-politológiai, hanem jogi kategóriává teszi azt! A törvény végrehajtásával, a valódi civil kezdeményezések, az öntevékenység fejlỏdését kívánja segíteni a jogalkotó. A preambulum az állami, önkormányzati közfeladatok ellátásába történő bevonás szükségességéről, partneri viszonyról beszél (segítség közpénzekkel, de a közvetlen kormányzati döntés elkerülésével). A poli- 
tikamentesség az NCA múködtetésének egyik alapelve. Ez a princípium, az eddigi tapasztalatok szerint, nehezen betartható, mert a választási rendszer (elektori szavazás) elég körülményes, a politika, látens módon beavatkozhat a regionális testületek (alulról felépülö [sic!]) tagjainak megválasztásába. Az NCA eddigi müködésének egy másik, sokkal nyilvánvalóbb anomáliája, hogy a finanszírozás, a központi költségvetés zárolásai miatt már az első években akadozott!

- A kormányzat civil stratégiájából következỏ másik jogi manifesztáció, az önkéntes munka jogi szabályozása (2005. évi LXXXVIII. törvény). Az önkéntes munka olyan jelentős társalmi erőforrásként fogalmazódik meg, amely a közcélok eléréséhez szükséges. A törvény „fogadó szervezeteket” felsoroló szakaszában szerepel az önkormányzat, az önkormányzati társulás, illetve alaptevékenysége körében a költségvetési intézmény. A jogszabály hatályba lépése óta eltelt rövid idő miatt egzakt tapasztalatok még nem állnak a rendelkezésünkre az eredményekről.

- A tanulmány szempontjából legfontosabb körülmény - erre az időszakra vonatkozóan -, az önkormányzatok civil koncepció alkotási hulláma. A koncepcióalkotás „szezonjának” a 2002-2006-os önkormányzati ciklust tekinthetjük. Ebben „komoly szerepe” lehetett a Medgyessy-kormány által elfogadott civil stratégiának, annál is inkább, mert a megismert települési koncepciókban explicit vagy implicit módon, de hivatkozások találhatók a kormány dokumentumra. A II. Gyurcsány-kormány idején a Szociális és Munkaügyi Minisztérium előterjesztésében „A kormányzati civil kapcsolatok fejlesztésének irányelvei" címmel 2006-ban egy újabb dokumentum készült, amely egyelöre még nem hivatalos kormányzati álláspont.

\section{Az együttmüködést példázó dokumentumok közös és eltérő vonásainak kivonatos bemutatása}

Az alábbiakban ismertetésre kerülő esetek bemutatásához szükséges forrásokat internet-kutatással, illetve a Szociális és Munkaügyi Minisztérium Társadalmi Párbeszéd és Civil Kapcsolatok Föosztálya adatbázisának felhasználásával gyüitöttük össze.

A keresést a városokra és a megyei jogú városokra terjesztettük ki. A feldolgozást a tartalomelemzés módszerével végeztük, melynek összefoglalását tesszük közzé ebben a tanulmányban.

Az itt felhasznált dokumentumok még a 2006-os önkormányzati választás elötti állapotot rögzítik. Az egyes önkormányzatok azóta hozott esetleges adekvát döntéseit értelemszerüen nem vette figyelembe a tanulmány.

A megismert civil koncepciók többségében kísérletet tettek a müfaj meghatározására, amely az alábbiakban foglalható össze: a koncepció feladata, célja, automatizmusok kialakítása, normativitás a helyi-térségi civil szervezetekkel kapcsolatban (áttekinthetö, kiszámítható, folyamatos, stabil rendszerek a támogatási formákban, az érdekegyeztetésben, a kommunikációban, feladat-átadásban). 
$\mathrm{Az}$ áttekintett és összehasonlított koncepciókkal kapcsolatban kijelenthetö, hogy megalkotásuk az önkormányzatok szándékát tükrözi, amelyet azzal a jövöbeni lehetỏséggel kívánnak feloldani, hogy a késỏbbiekben azok egy írásba foglalt együttmüködési megállapodás alapjai lehetnek, de a partneroldalon a megfelelő (ernyö)szervezet (civil szövetség) inkább cél, mint kézzelfogható valóság. Nem ismerjük minden településen a koncepcióalkotás elözményeit, az esetleges egyeztetési folyamat részleteit - akár az egyes civil szervezetekkel, akár a képviseletükre jogosultakkal -, éppen ezért csak a tartalomelemzés alapján állítjuk, hogy inkább a helyi hatalom akaratának megnyilvánulásával találkoztunk. A dokumentumok helyzetelemzéseikben térnek ki a településsel kapcsolatos sajátosságokra, a már kialakított együttmüködési formák felsorolására. Székesfehérváron például egy helyi kutatás adataira hivatkoznak. Több dokumentum a korábban elért eredményekkel, problémákkal (finanszírozási rendszer, civil referens, civil kerekasztal) kapcsolatos tapasztalatok összefoglalására, rendszerezésére törekszik (1. táblázat).

A fellelt koncepciók között akadt több is, amelyekben kardinális, illetve vertikális és horizontális célok fogalmazódnak meg, és azok tartalma, szinte szóról-szóra megegyezik (feltehetően közös mintából, forrásból).

$\mathrm{Az}$ áttekintés alapján levonható egyik következtetés, hogy kevés célkitüzést fogalmaztak a valóban helyi célokról, problémákról. A másik megjegyzésünk: fából vaskarikának tủnik a helyi hatalom igyekezete, amellyel a civil társadalom fejlesztését tekinti egyik fố céljának, ahogy a vertikális céloknál szereplő állítás is, amely a civil-civil párbeszéd fejlesztését irányozza elö!?

Nyíregyházán a környezetvédelem, a közmúvelődés és a szociális ellátás területén kibontakozó együttmüködés változatai részletes kifejtésre kerültek a koncepcióban.

Nagykanizsán a közfeladat-ellátásban konkrét szervezetröl (Vöröskereszt) tesz említést a dokumentum.

Nagykanizsán Civil Szolgáltató Központ (CISZOK) felállítása jelenik meg igényként, mivel „csak” a megyeszékhelyeken van Nonprofit Szolgáltató Központ.

Veszprémben és Nyíregyházán a civil szervezetek elismerésének igénye fogalmazódik meg a dokumentumban.

Szekszárdon elkészült az együttmüködési megállapodás a civil koncepció alapján a Szekszárdi Civil Kerekasztal és az önkormányzat között!

A megismert dokumentumok jellemzően a következő területeken jelölik ki az önkormányzat feladatait: a döntés-előkészítésbe való bevonás intézményei; együttmüködés, kommunikáció módozatai; feladatátadás, -átvállalás, a civil szervezetek támogatása (benne pénzügyi, természetbeni, szolgáltatásokkal történö), illetve a civil szervezetek elismerése. 
Brachinger Tamás : A civil kezdeményezések hatása a városi kormányzásra.

Tér és Társadalom 22. évf. 2008/1. 93-107. p.

TÉT XXII. évf. 2008 - 1

A civil kezdeményezések hatása a ...

103

\section{TÁBLÁZAT}

A vizsgált civil koncepciók SWOT-elemzése

(SWOT Analysis of Examined Civil Concepts)

Erösség: Gyengeség:

- Célok, szándékok manifesztálód- - Többségében egyoldalú „szánnak, rendszereződnek; déknyilatkozat";

- Hangsúlyozzák a civilek autonó- - Kevés figyelmet kap a közfemiáját, függetlenségét; ladat-ellátás;

- Helyzetelemzés, az addig elért - Kevéssé van tekintettel a helyi eredmények áttekintése is része a sajátosságokra, a megfogalmadokumentumoknak. zások sablonosak;

- Egyelőre csak a megyeszékhelyeken van civil infrastruktúra.

Lehetőség:

- Célok, szándékok világos politikává válhatnak (rendeletalkotásban, együttmúködési megállapodásban);

- Civilek koncepciózusan vállalhatnak részt a programok megvalósításában, partnerség, sỏt, governance lehetősége.

\section{Veszély:}

- Szépségtapasz, hivatkozási lehetőség lehet, amely bemutatja, hogy „felvilágosult" a helyi hatalom;

- Olyan elvárásokat fogalmaz meg, amely elsősorban a helyi hatalom szereplőinek attitűdjét tükrözi;

- Amennyiben nincs partner a civil oldalról, nem hasznosul, nem válnak megvalósítható programmá a koncepció kijelölte célok;

- Nem feltétlenül igazodik az adott önkormányzat stratégiájához, illetve ágazati koncepcióihoz.

Forrás: Saját szerkesztés.

\section{Baja Város Önkormányzata civil szférával való együttmüködésére vonatkozó koncepciójában foglaltak érvényesülése}

A tanulmány fókuszában álló évtizedes együttműködés áttekintése mellett röviden szeretném összefoglalni készülő doktori értekezésem hasonló irányú vizsgálatainak megállapításait.

A kutatást Baja városában végeztem.

A Baján folytatott vizsgálat három ütemben zajlott. A vizsgálat célcsoportjai a helyi hatalom, illetve a helyi közösségek reprezentánsai.

Az első ütemben a helyi hatalom szereplőinek körében gyüjtötttünk adatokat. Tekintettel arra, hogy egy-egy választási ciklus csupán négy év, az 1990 választási ciklustól a 2002-es választási ciklusig minden települési képviselőt és külső bizottsági tagot figyelembe vettünk, mert a döntéshozó kritériumának - képviselő-testület 
tagjaként, állandó bizottság tagjaként - ez a kör felelt meg. Alkalmazott módszerek: survey és attitüd vizsgálat.

A második ütemben a helyi civil közösségek képviselöinek körében vizsgálódtunk. Az akkori statisztika szerint 284 nonprofit szervezetnek volt bajai székhelye. A vizsgálatot ebben az esetben is a teljes körre kiterjesztettük, kivételt az önkormányzati alapítású nonprofit szervezetek jelentettek. Alkalmazott módszerek: survey és attitủd vizsgálat.

A harmadik ütemben készültek az interjúk. Jelen fejezetben az önkormányzat 2003 decemberében elfogadott „Az önkormányzat és intézményeinek civil szervezetekkel folytatott együttmüködésének koncepciójáról" szóló dokumentum érvényesülésének rövid értékelésére szorítkoznánk.

A koncepció megalkotásának előzményei között egy generális és speciális körülményt érdemes megemlíteni. Az általános körülmény a tanulmányban már korábban említett kormányzati civil stratégia, amelyet szintén 2003-ban alkottak meg. A bajai dokumentum „vastagon" hivatkozik a kormányzati civil stratégiára. Ezt, csakúgy, mint a többi, vizsgálatban szereplö önkormányzati civil koncepció többségénél, forrảsként értékelhetjük.

A speciális körülmény, hogy a civil koncepció elökészitésében és elkészitésében komoly szerepet játszik egyetlen személy, akinek a vizsgált időszakban viselt tisztségei „összeadódnak”, ezzel a készülő civil koncepció jelentőségét akár növelhetnék is, de egyúttal annak autentikusságát veszélyeztetik. A szóban forgó aktor egyszerre volt a Bajai székhellyel müködö Bácskai Civil Szervezetek Szövetségének (BÁCISZ) elnöke és a kérdéses időszakban a városvezető koalíció nagyobbik képviselö-csoportjának vezetője, továbbá a civil kapcsolatokért felelös tanácsnok. A BÁCISZ aktivistái és tisztségviselöi között további személyeket találtunk, akik ezzel a kettős identitással rendelkeztek.

Ad absurdum így a „civil reprezentációt” a koncepció megalkotásánál adottnak tekinthetjük, de ha komolyan vesszük a programalkotási folyamatot, mégiscsak a helyi hatalom által megalkotott koncepcióról beszélhetünk, amely kevéssé tükrözi (tükrözheti) az amúgy is fragmentált helyi civil társadalom közös érdekeit, elképzeléseit. A BÁCISZ-nak nem csak bajai, hanem térségbeli, vajdasági, sőt, budapesti tagszervezete is van, viszont a bajai székhelyü civil szervezetek nagyobb része egyáltalán nem tagja.

A BÁCISZ, ez a helyi statútumból derül ki, állandó meghívottja a képviselötestület és az egyes szakbizottságok üléseinek, amelyeknek más, a BÁCISZ-on kívüli civil meghívottjai is vannak.

A civil koncepció lényegében egy elöterjesztés melléklete, amely meglehetôsen kidolgozatlan. Az elöterjesztés tartalmaz egy helyzetelemzést, részletesen ismerteti a kormányzati civil stratégiát és az érdekeltek együttmüködésének föbb területeit is számba veszi. A határidők az egyes célok tekintetében régen lejărtak és a célok többségében egyáltalán nem teljesültek. Az alábbiakban ezeket a célokat ismertetjük.

Elhatározták, hogy az önkormányzat a teljes körủ tájékozódás és tájékoztatás érdekében a civil szervezetekkel együttmüködésben összeállítja a városi székhelyü 
vagy telephelyü, múködő civil szervezetek, alapítványok és egyesületek egységes nyilvántartását. A nyilvántartás nem készült el, a határidő 2004. III. 31-én lejárt.

Célul tüzték ki a városi Civil Tanács megalakítását. A tanács létrehozása érdekében ágazati kerekasztalok összehívását kezdeményezték. A Civil Tanács nem alakult meg, a határidỏ 2004. IV. 30-án lejárt.

Az önkormányzat elhatározta, hogy gazdasági programjával összhangban - ha a feladatellátás azt igényli -, kölcsönös elönyök alapjăn, a szolgáltatás hatékonyabb biztosítása érdekében közfeladat ellátására szerződéses formában megállapodảst köthet arra vállalkozó civil szervezettel. Ennek a törekvésnek a civil koncepciótól függetlenül előtte is és azóta is kialakult gyakorlata volt/van, ami múködőképes.

Megfogalmazódott, hogy a civil szervezetek részére támogatást ad önkormányzati feladatok ellátása, átvállalása esetén: A támogatás tervezett formái:

„Ingyenes létesítmény, intézmény, közösségi tér használata, kedvezményes térítésủ létesítmény, intézmény, közösségi tér használat, program finanszírozás pályázat alapján, továbbképzési támogatás pályázat alapján, hozzájárulás pályázati önerőhöz - pályázat keretében."

A civil koncepciótól függetlenül előtte is, és azóta is kialakult, működőképes gyakorlata volt/van a támogatásoknak; vannak úgynevezett kiemelt civil szervezetek, amelyek támogatása önálló előirányzatként szerepel az éves költségvetési rendeletben, szakbizottságok átruházott hatáskörében a sport, a kultúra és az ifjúsági kezdeményezések területén volt, illetve van pályázati alap; pályázati önerőre is lehet pályázni, ahogyan a létesítményhasználat biztosítására is. A polgármesteri hivatal állományában korábban sem dolgozott és ma sem dolgozik civil referens. Ezt a tényt önmagában nem értékeljük problémaként, mert a városban müködő civil szervezetekkel való együttmüködés több köztisztviselönek is munkaköri kötelessége, legfeljebb a civilek számára ez nem mindig nyilvánvaló.

Megfogalmazásra került, hogy a város a civil szervezetekkel közösen indulva pályázati forrásból is biztosítani kívánja az úgynevezett Civil Szolgáltató Központ - Civil Ház, Mủvészetek Háza és Kézmüves Ház létrehozását, illetve méltó elhelyezését.

A szóban forgó létesítmények azóta sem léteznek, de ettỏl fưggetlenül a ténylegesen működő civil szervezetek elhelyezése közösségi intézményekben, illetve közérdekủ bérlökijelölés alapján megoldott a városban; krónikus elhelyezési problémáról nem beszélhetünk.

A koncepció célul tủzte ki, hogy a civil szférával történő együttmüködés föbb feladatait, valamint a finanszírozás kereteit önkormányzati rendelet keretében szabályozza.

A rendelet megalkotására mostanáig nem került sor.

Az említett személyes érintettség nemcsak az autentikusságot veszélyeztette a helyi hatalom és helyi civil társadalom viszonyában, hanem a végrehajtást is kontraproduktívvá tette, hiszen ez a körülmény kioltotta a külső civil kontroll, a civil nyomás ősztönző erejét.

A bemutatott célkitủzések érvényesülésére az aktuális választási ciklusban sem látunk sok esélyt, tekintettel arra, hogy a 2006-os választások gyökeresen megváltoztatták az önkormányzat összetételét. A megkezdett ciklusban tanácsnok felügyeli 
az önkormányzat társadalmi kapcsolatait igazi feladat- és hatáskör, egyszóval tartalom nélkül. A 2003-as civil koncepció egyes elemei, bizottsági, képviselöi vagy frakció kezdeményezésként visszatérhetnek a döntéshozók elé, hiszen a célkitüzések régóta fennálló problémák megoldását szolgálták volna, és nem zárható ki, hogy egyes civilek kezdeményezőleg lépnek fel. A jelenlegi városvezetés számára, legalább is az eddig megfigyelt viszony alapján, a BÁCISZ nem partner. Valódi, városi szintủ civil képviselet korábban sem volt és most sincs. A civil szervezetek kezdeményezései inkább egyedi, szórványos megkeresések.

Nem tértünk ki a bajai civil szervezetek felelösségének értékelésére a civil koncepció célkitüzéseinek teljesítésében. Kétségtelen, a célkitüzések megoldása krónikus problémák megoldását tenné lehetővé. A bajai civil szervezetekkel kapcsolatos adatok átfogó kiértékelése még hátra van.

Ami az eddig rendelkezésünkre álló adatokból már megállapítható, legyen szó akár pénzbeni támogatásról, akár ingatlan használatról, akár feladatátvállalásról, a bajai civil szervezetek attitüdjeiben is hangsúlyos elem, hogy az önkormányzat szerepvállalásának dominánsnak kell lenni, tehát annak kiváltására nem mindig indul be az öntevékenység, alternatívák keresése, hanem inkább egy passzív időszak következik.

Végül még egy említésre méltó körülmény: a civil szervezeteket képviselő megkérdezettek jelentős része nem is tudta, hogy az önkormányzat megalkotta a szóban forgó dokumentumot. Megkérdezésükre 2005 nyarán, tehát másfél évvel a koncepció elfogadása után került sor. A legmegdöbbentőbb azonban az volt, hogy a döntéshozók körében sem volt mindenki számára nyilvánvaló, hogy elkészült ez a koncepció. Ennek a körnek a felmérése 2004 tavaszán-nyarán történt! Kétségtelen tény, hogy ebben a körben nemcsak az „aktív” helyi politikusok, hanem a korábbi ciklusokban szerepet vállaló döntéshozók is szerepeltek. Azonban róluk is feltételezzük az átlagosnál nagyobb tájékozottságot a helyi közéletről, hiszen ,passzív” időszakukban sem szakadnak el többségükben szervezeteiktől.

\section{A generális tapasztalatok összefoglalása}

Az önkormányzati rendszer elmúlt másfél évtizedének története elegendő intézményes megoldással szolgált. Ezek a változatos, de mégiscsak egy irányba húzó keretek megfelelö fundamentumai, hardware-i a kooperációnak és a partnerségnek. A felek eddigi együttmüködésük során számtalanszor kerültek szereptévesztésbe. Ennek két jellemző példáját ismerhettük meg:

1) A politikai versenybe bekapcsolódó civil szervezetet, amelynek nemkívánatos következményeként - még lokálisan is - kiforgatható a civil lelkület, meghasonlik a civil identitás.

2) A nonprofit szervezetek alapításában részt vevő önkormányzatot, amely gyakorlati okoktól vezérelve a kilencvenes években gyakran lépett „kényszertársadalmasítás" útjára, hogy „mentse, ami menthetö”. 
A kooperáció, a partnerség, a „local governance” gyakorlásának feltétele az, hogy a civil koncepciókban megfogalmazott magatartások tartóssá, tudatossá és kölcsönössé váljanak. Az együttmüködés szubjektív feltételének is tekinthetjük az elöbbiekben ismertetett elvárást, de az eddigi tapasztalatok szerint ez még gyakran hiányzik.

Az önkormányzatok koncepcióalkotási szándékát biztató jelnek tekinthetjük, mivel az szemléletváltásra utalhat. A kiszámíthatóság, a normativitás, a tartós együttmüködés mindkét félnek hosszú távú érdeke.

A cél közös: a településközösségek fenntartható fejlódése, amelyet a közvetlen demokrácia minőségével, a részvétel, a közremúködés intenzitásával minösíthetünk igazán. Ennek mérése igazi metodikai kihívás, kvalitatív módszereket és mikroszintủ vizsgálatok sokaságát igényli.

\section{Irodalom}

Böhm A. (1996) Helyi társadalom. CSVMTF, Budapest.

Brachinger T. (2000) Nonprofit alapismeretek. EJF, Baja.

Brachinger T. (2001) A legkisebb közös többszörös. - Parola. 4. 3-5. o.

Brachinger T. (2005) Civilek és politikai hatalom. - Civil Szemle. 1. 45-59. o.

Csegény P.-Kákai L. (2000) Civil szervezetek megjelenése a helyi statútumokban. - Köztes helyzet!? A civil szervezetek és az önkormányzatok kapcsolatában az ezredforduló Magyarországán. MEH Civil Kapcsolatok Föosztálya, Budapest. 72-87. o.

Kéri L. (1997) A civil szféra a '90-es évek Magyarországán. - Sansz. 10.12. o.

A Magyar Köztársaság Kormányának Civil Stratégiája. (2003) www.civil.info.hu

A nonprofit szervezetek föbb statisztikai jellemzöi 2003. (2005) KSH, Budapest. www.ksh.hu

Pálné Kovács I. (1990) A helyi politika. Akadémiai Kiadó, Budapest.

Salamon, L.M. (1991) A piac kudarca, az öntevékenység kudarca és a kormány nonprofit szektorral kialakított kapcsolatai a modern jóléti államban. - Kuti E.-Marschall M. (szerk.) A harmadik szektor. Nonprofit Kutatócsoport, Budapest. 65-68. o.

Sebestény I. (2002) Az önkormányzatok és a nonprofit szervezetek kapcsolata 2000. KSH, Budapest.

\section{IMPACT OF CIVIL INITIATION ON LOCAL GOVERNANCE}

\section{TAMÁS BRACHINGER}

This project is part of my $\mathrm{PhD}$ thesis in the field of social science. In this project we were examining the co-operation between the civil organisations and the local government in Hungary. Analysing the development of participation and co-operation of the last one and the half decade this study gives an overview of development tendencies in the domestic civil society. In this case, the subjects my study's is so-called civil conceptions of Hungarian towns. The Hungarian local governments don't have to frame such documents. It is only an opportunity for them to improve their relations with the local interested parties.

The applied method in this study was contents analysis. The base of the analysis was the civil conception. The conceptions were overviewed. They are similar to each other, because therein aren't lots of self-contained idea. My dilemmas were; interests are reflected in these documents? It was evidenced that It is reflecting the interests of the local governments rather than the interests of the local civil parties. 